\title{
Senegal: Mainstreaming adolescent health: Building on local support systems
}

Frontiers in Reproductive Health

Follow this and additional works at: https://knowledgecommons.popcouncil.org/departments_sbsr-rh

Part of the Demography, Population, and Ecology Commons, Family, Life Course, and Society Commons, International Public Health Commons, Maternal and Child Health Commons, and the Medicine and Health Commons

How does access to this work benefit you? Let us know!

\section{Recommended Citation}

"Senegal: Mainstreaming adolescent health: Building on local support systems," FRONTIERS OR Summary no. 64. Washington, DC: Population Council, 2007. 


\section{Senegal Youth}

OR Summary 64

\section{Mainstreaming Adolescent Health: Building on Local Support Systems}

Support from multiple ministries, youth, and the community facilitated the expansion of adolescent reproductive health activities in Senegal. Routine budgetary allotments and in-service training at all participating ministries is essential for full mainstreaming of youth reproductive health.

\section{Background}

In 1999, FRONTIERS began a three-year collaboration with the World Health Organization (WHO), the Ministries of Health (MOH), Education (MOE), and Youth (MOY), the Center for Research and Training (CEFOREP) and the Population Training Group (GEEP) to test the feasibility, effectiveness and cost of school-, clinic-, and community-based interventions to improve the reproductive health of youth aged 10-19. This adolescent reproductive health (ARH) study showed that the multisectoral, multidisciplinary

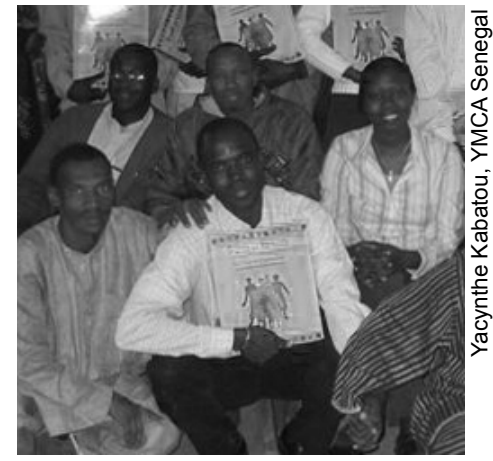
Grandir en Harmonie life skills curriculum.
Recently certified YMCA trainers with the

approach increased knowledge about youth reproductive health among young people, the community, schools, and health care providers (see OR Summary No. 35). The overall positive findings prompted a follow-on effort, launched in 2004, to create a favorable policy and funding environment for adolescent reproductive health (ARH), institutionalize ARH programs in the study districts, and scale up the intervention in Senegal and beyond, to other Francophone African countries.

FRONTIERS provided technical assistance to the $\mathrm{MOH}, \mathrm{MOE}$, and MOY to reinforce their capacity to develop and implement measures to improve adolescent reproductive health. FRONTIERS is presently providing technical assistance to help the MOH build the ability of service delivery organizations to develop and implement multisectoral interventions.

\section{Major Factors in Sustainability}

Several elements enhanced the sustainability of the ARH activities in Senegal, as follows:

- Multisectoral links. The direct involvement of multiple government agencies and community sectors established the importance of adolescent reproductive health as a broad social and policy concern. Strong endorsement from WHO gave further impulse to the multisectoral approach.

- Research targeted to local needs. Findings from the pilot operations research study were key for sustaining ARH activities because they built on a scientific method of inquiry. In addition, the project answered a local need: policymakers, communities, and parents were aware of the need to address ARH, which facilitated a strong commitment to the effort.

- Use of existing institutions. One of the guiding principles of the ARH study was to build sustainability through existing institutions, rather than establishing new agencies. For example, the partnership between youth associations and publicsector health facilities resulted in unusually high commitment and retention of peer educators. The peer educators trained during the pilot project are now training new groups of peer educators. 
- Long-term investment. Addressing ARH required a significant policy and social shift that occurred over a period of several years. A major element in the project's sustainability was the continuing support from USAID, through technical assistance from FRONTIERS, during this transition. Ideally, this support will shift to Senegalese government and nongovernment agencies as ARH is mainstreamed.

\section{Utilization}

- $M O H$. Since 2004, the MOH has led the development of an inter-ministerial coordination body to guide ARH activities and the expansion of project elements to all areas of Senegal. The $\mathrm{MOH}$ identified adolescent reproductive health as a strategic priority and has included it in the 2005 revision of national health guidelines. A National Strategy on Adolescent Health in Senegal was finalized and publicly launched in 2006. FRONTIERS helped the $\mathrm{MOH}$ prepare guidance on developing and costing ARH operational plans, and this guidance has been distributed to all health districts.

- ARH curricula. The educational and training curricula developed during the pilot study were adopted as national documents with assistance from FRONTIERS. These curricula will be used to teach ARH to in-school youth, train providers on youth-friendly services, and train peer educators working in youth centers.

- External support. The project's success has leveraged support from within and beyond the participating ministries. A variety of entities, including the Ministry of Youth, the Ministry of Justice, local faith-based organizations, the Afri- can Development Bank, and UNFPA, are supporting the use of project materials and their expansion into new areas or audiences.

- Youth support. Youth networks used the capacity building delivered in the pilot phase to attract funds from donor agencies. For example, the YMCA, with funding provided by the World Bank through the National AIDS Council, is implementing ARH activities among 200 youth networks throughout Senegal.

\section{- Expansion beyond Senegal. A national ARH} strategy was developed in Guinea with technical assistance from FRONTIERS and the Senegalese $\mathrm{MOH}$. The Mauritanian Ministry of Education is adapting and translating the community ARH curriculum, Grandir en Harmonie [Growing up in Harmony] into Arabic, with financial support from UNICEF and UNFPA.

\section{Policy Implications}

- Full sustainability for ARH activities, as well as synergistic use of resources, requires routine strategic planning and the allocation of resources and funding within annual work plans and budgets in the sectors involved.

- Staff turnover at the MOH and MOY has impeded the mainstreaming process by removing personnel with expertise in working on ARH issues. Institutionalizing ARH in pre-service training is necessary to ensure awareness of youth reproductive health needs. Additionally, establishing monitoring and evaluation indicators for quarterly reporting would ensure accountability of new staff for ongoing ARH activities.

Source: Diop, Nafissatou and Anta Fall Diagne. 2007. "Mainstreaming adolescent reproductive health: Enhancing utilization of the findings from the youth reproductive health project," FRONTIERS Report. Washington, DC: Population Council. See also: "Senegal: Involve community networks in adolescent reproductive health," FRONTIERS OR Summary no. 35. Washington, DC: Population Council, 2003. Both available on our website at www.popcouncil.org/frontiers/finalreports.html or by e-mail: frontiers@pcdc.org

This publication is made possible by the generous support of the American people through the United States Agency for International Development (USAID) under the terms of Cooperative Agreement No. HRN-A-00-98-00012-00. The contents are the responsibility of the FRONTIERS Program and do not necessarily reflect the views of USAID or the United States Government. 